\title{
Ministries cooperate to plan Japanese genome centre
}

Tokyo

Japan's struggling genome research sector will be boosted by the opening of a new centre, the result of cooperation between several ministries. The centre's director will coordinate the country's research on the application of single-nucleotide polymorphisms (SNPs).

The centre, for which the Science and Technology Agency (STA) has set aside $¥ 1.9$ billion (\$18 million), will be located in Yokohama at Riken's Genomic Sciences Centre. In the past, Tokyo University's Institute of Medical Sciences and Tokushima University accounted for most SNP research in Japan.

Under Prime Minister Keizo Obuchi's Millennium Project, more than 20 universities and several foundations, consortia, and public and private research institutions will work together in an initiative sponsored jointly by STA, the Ministry of Education, Sports and Culture (Monbusho), the Ministry of Health and Welfare (MHW) and the Ministry of International Trade and Industry (MITI).

The project will draw together several strands of research, from the sequencing of 30,000 full-length complementary DNAs and the identification of 150,000 SNPs, to SNP frequency analysis, construction of reference databases, diagnostic screens, and pharmaceutical and medical applications.

Kumao Toyoshima, of Sumitomo Hospital in Osaka, is tipped as the probable new director. He will be expected to coordinate research that leads from SNP databases to practical applications in five key areas: cancer; metabolic disorders such as diabetes; circulatory disorders such as high blood pres- sure; immunological disorders; and dementia. This will mean working closely with Tokyo Medical Centre and the MHW's National Cancer Centre.

The centre is well funded, but some people are concerned that the involvement of several ministries and institutions may lead to inefficiency. One senior researcher criticizes what he calls a "budget first, strategy later" approach in which money is first allocated to the ministries, which decide how to distribute funds among their own institutions.

Critics say that a better alternative would be to determine the research needs of the various institutions in an interministerial committee and then allot money accordingly. The top-down strategy also leads to some unnatural divisions in research structure, such as between the identification of SNPs and the search for disease-related genes.

Funding in the new plan is focused on identifying SNPs, rather than medical applications. One senior researcher speculates that structuring the project as five divisions probably stems from demands by the five ministries to appoint a division leader each.

The success of the project will depend on researchers' ability to overcome bureaucracy and integrate their research. But many are hopeful that they can do this, and enthusiastic about the government's recent push into SNPs research (see Nature 399, 295; 1999).

Masaaki Terada of the National Cancer Institute believes that researchers will coordinate their efforts to avoid doubling up on research projects. "They are competitive, but they do not want to waste their time doing the same thing as someone else." David Cyrano

\section{Top physicist quits Japan for US}

Tokyo

Shuji Nakamura, who pioneered the development of blue light-emitting diodes (LEDs), is leaving Japan to take up an academic position in the United States.

Nakamura worked on gallium nitridebased LEDs and laser diodes at Nichia Chemicals, a privately owned manufacturer of fluorescent materials. He is taking up a professorship at the University of California, Santa Barbara, starting in February.

Following the demonstration of a workable blue laser, now commercially available, Nakamura says there was little left for him to achieve at Nichia.

According to Nakamura, many industrial researchers are leaving Japan for better work-

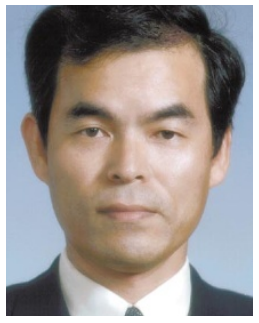

ing conditions in the United States. "Japanese industrial research and development may be on its way to becoming obsolete."

Nakamura, who has not made up his mind about future research, Nakamura: leaving says he did not receive for better conditions. any offers from Japanese companies or universities, but cannot imagine working for a Japanese university. "Because of numerous regulations, Japanese universities do not provide an environment where researchers can work freely."
Robert TriendI
Issue of patents on 'Dolly' technology stirs controversy

\section{Washington}

The first patents on the technology used to clone Dolly the sheep were issued last week, three years after its inventors published news of Dolly's birth (see Nature 385, 810-813; 1997).

The two British patents, issued on 19 January to the Roslin Institute and the two government agencies that supported its work, cover a broad variety of applications of the cloning technology, but exclude human reproductive cloning. In all, the patents cover 58 claims to methods of producing cloned non-human animals, human cell lines and early human embryos, and to the animals, embryos and cell lines produced in this way.

Other patents have already been issued for cloning technology that differs from the Roslin method, but covering only animals. The Roslin patents cover the cloning and growth of a human embryo to the level of the blastocyst, an early embryonic stage.

Separately, the US Patent and Trademark Office has issued a notice of allowance for a patent application on Roslin's cloning technology, also called nuclear-transfer technology. A US patent on the technology is therefore likely to be issued within months.

The US patent is limited to techniques for cloning non-human mammals, but the inventors are expected to follow this up with an application encompassing human uses.

"This is the first time anyone has had a patent issue on a nuclear-transfer technology that would cover its use in human cells," says David Earp, vicepresident of intellectual property at Geron Corporation of Menlo Park, California. He says this puts his company in a "dominant position".

Geron, which last year acquired Roslin Bio-Med, a company set up by the Roslin Institute to develop its cloning technology (see Nature 399, 92; 1999), holds an exclusive licence on the Roslin patents and underlying technology, with one exception - PPL Therapeutics Ltd holds a licence to use the technology to produce certain human proteins in the milk of ruminants and rabbits.

Geron hopes to combine the cloning and stem-cell technologies to develop therapies for a range of diseases from diabetes to Parkinson's disease.

The idea is to use nuclear-transfer technology to produce a genetically 


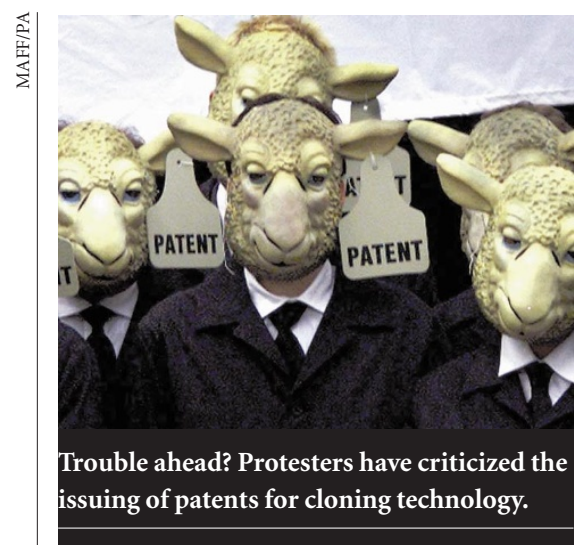

$>$

identical embryonic stem cell from a patient's own cell, then to cause the cell to differentiate into the kind needed for therapy - pancreatic cells in diabetes, for instance, or dopamine-producing neurons in Parkinson's disease. The potential therapeutic applications leave Earp "excited". "There are huge medical advances at our fingertips," he says.

The patents were criticized last week from various sides. "Organizations, including charities, may not have the money to pay to use this patent technology," Vivienne Nathanson, head of science and ethics at the British Medical Association, told BBC Television. "So this could inhibit medical research."

"It's going to break the health-care system," adds Jeremy Rifkin, who heads the Washington-based Foundation on Economic Trends. "If Geron and Roslin can get a lock on stem cells and [cloned] embryonic cells, they then have total control over future medical developments in this area of research."

Rifkin says he is distressed by the UK patent office's "chilling" and

"unconscionable" decision to grant a patent on the earliest form of human life. He argues that patents should pertain only to inventions, not to naturally existing entities, such as humans. The decision, he says, is "an absolutely transparent violation of the patent statutes in virtually every country. This is something my attorneys are going to move on immediately with formal legal protests in the UK."

But Arthur Caplan, director of bioethics at the University of Pennsylvania, says Roslin has rightfully won the patents. "They've got the products and the uses as well as the technique." He adds: "It's time to shift the issue to a discussion of what responsible [patent] ownership is."

Geron's Earp says the company has "absolutely no intention" of inhibiting medical research. "We want to openly encourage as many people as possible to do basic research" using cloning and stem-cell technologies. Meredith Wadman

\section{US survey reveals location of human tissue samples}

\section{Washington}

A survey to be published next week will show the whereabouts of more than 300 million human tissue samples archived in the United States. The survey's authors hope it will form the basis for a comprehensive database of samples and increase their availability to the growing army of researchers who need them.

The Handbook of Human Tissue Resources, to be published by the Science and Technology Policy Institute at the Rand Corporation, attempts to provide comprehensive information on the hundreds of human tissue archives. These range from tens of millions of samples held by the Armed Forces Institute of Pathology to scattered collections in university departments across the United States.

"It is difficult for researchers to know what samples are out there, and what they need," explains Roger Aamodt, chief of the resources development branch at the National Cancer Institute (NCI). Aamodt's work compiling data on tissue samples from cancer patients helped form the basis for the broader Rand survey. "For the first time, the handbook puts this information in one public document."

Aamodt says there is "an incredible growth curve" in demand from researchers for human tissue samples, most of which were collected by pathologists without anyl intention that they would be used for research. But progress in genetics is turning these collections into powerful research tools. The Cooperative Human Tissue Network, which was established by the NCI in 1987 to obtain tissue samples for cancer researchers, distributed 50,000 samples last year to more than 500 investigators.
Aamodt suggests that the guide will be particularly useful for researchers at smaller institutions lacking specialist facilities to help their scientists find samples.

Rand started gathering information on US tissue sample archives for the National Bioethics Advisory Commission when it was preparing guidelines governing the circumstances in which the samples could be used in research. Many patients had not given informed consent to their samples being used in research, and there are concerns about the privacy of the genetic information they contain. The commission published its guidelines last year, and Rand has decided to publish the survey's results as a research tool.

Elisa Eiseman, the survey's chief author, says it should serve as a resource for basic and clinical research into many diseases. She adds that Rand is talking to the NCI and the International Society of Biological and Environmental Repositories about putting the survey's contents on the Internet. Colin Macilwain

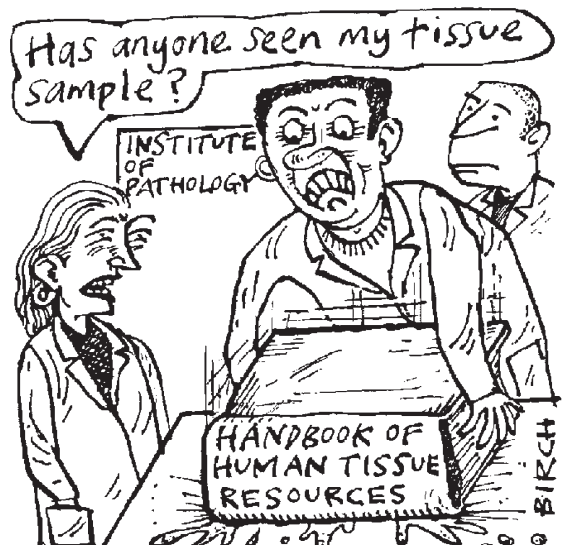

\section{India targets extra research funds}

\section{New Delhi}

A $\$ 500$ million annual increase for the next five years in funding for Indian science and technology, promised by prime minister Atal Behari Vajpayee, will be used to boost basic research, modernize laboratories, and launch new technology missions, according to officials in the science ministry.

Valangiman Ramamurti, secretary for the Department of Science and Technology, says the news "has come at a time when funding for even routine basic research was steeply on the decline and several good proposals from universities had to be turned down".

Earlier this month, Vajpayee said that his government, led by the Bharatiya Janata
Party, would provide funding worth 1 per cent of the gross domestic product for research and development in the financial year beginning 1 April 2000, increasing to 2 per cent in 2004 (see Nature 403, 126; 2000).

Ramamurti says that the heads of scientific agencies who met with finance minister Yashwant Sinha were given the impression that the increases would be reflected in the fiscal year 2000 budget.

According to Ramamurti, the additional resources would be spread across various scientific agencies under different ministries. At least 30 per cent would be used to boost basic research, with 20-30 per cent to go on "infrastructure creation". $\quad$ K. s. Jayaraman 